\title{
TRADITIONAL KNOWLEDGE AND PERCEPTIONS TOWARDS THE ANDEAN CONDOR (Vultur gryphus LINNAEUS, 1758) IN THE CENTRAL ANDES OF COLOMBIA
}

\author{
CONOCIMIENTO TRADICIONAL Y PERCEPCIONES HACIA EL CÓNDOR ANDINO \\ (Vultur gryphus LINNAEUS, 1758) EN LA CORDILLERA CENTRAL DE COLOMBIA
}

\author{
Juan Sebastián RESTREPO-CARDONA ${ }^{1 *}$, Fausto SÁENZ-JIMÉNEZ², Alan A. LIEBERMAN³
}

${ }^{1}$ Programa de Maestría en Conservación y Uso de Biodiversidad, Facultad de Estudios Ambientales y Rurales, Pontificia Universidad Javeriana, Transversal 4 No. 42-00, Piso 8, Bogotá, Colombia, 110231. 2 Fundación Neotropical, Bogotá, Colombia. Carrera 6 No. 1 -11, Cajicá, Colombia, $250240 .{ }^{3}$ San Diego Zoo Global, Institute for Conservation Research, P.O. Box 120551, San Diego, California, USA, 92112. *jsrestrepoc@gmail.com

\begin{abstract}
Despite its cultural importance as a key component of the Andean landscape, some perceptions of rural inhabitants towards the Andean condor (Vultur gryphus Linnaeus, 1758) persist, as they relate to the possible predation of domestic animals such as sheep and cattle. These perceptions are compounded by only a basic knowledge of the natural history of the species and have resulted in the historical persecution of the condors by the local peasant communities. We studied the variation of traditional knowledge about the Andean condor diet; comparing responses of adult women and adult men and adults and young people. We described the perceptions of rural farmers towards V. gryphus in Caldas and Tolima, Central Andes of Colombia. Adult men demonstrated a more detailed knowledge of the types of food of $V$. gryphus compared to adult women; but both adult men and women responded more accurately than both sexes of young people. Overall, the perceptions towards the condors were mostly positive. It is likely that the greater knowledge of adult men corresponds to the time they spend outdoors tending their crops and animals, while the younger generation receive their information through popular media, such as television, magazines and books, as well as educational materials. It is important to incorporate the gender perspective into conservation initiatives and educational programs to effectively protect the remaining endangered populations of condors in Colombia.
\end{abstract}

Keywords: Conservation; Critically Endangered species; Gender perspective; Rural landscape.

\section{RESUMEN}

Pese a su importancia cultural como componente clave del paisaje Andino, las percepciones de pobladores rurales hacia el cóndor andino (Vultur gryphus Linnaeus, 1758), relacionadas con la posible depredación de animales domésticos como ovejas y vacas, sumado al poco conocimiento de la ecología de la especie, pueden desencadenar persecución a los cóndores. Estudiamos variación del conocimiento tradicional sobre los tipos de alimento de $V$. gryphus, entre mujeres y hombres adultos y entre adultos y jóvenes, y describimos las percepciones de pobladores rurales hacia la especie en Caldas y Tolima, Cordillera Central de Colombia. Los hombres adultos tienen un mejor conocimiento sobre los tipos de alimento de $V$. gryphus en comparación con las mujeres adultas y así también ese conocimiento es mayor en adultos que en jóvenes. Las percepciones hacia los cóndores fueron mayormente positivas. Es probable que el mejor conocimiento de los hombres adultos corresponde a que han tenido una relación más directa con el campo y las aves del territorio; mientras que actualmente los jóvenes reciben la información a través de otros elementos como la televisión, las revistas, los zoológicos y los materiales educativos. Es importante integrar la perspectiva de género en iniciativas de investigación social y programas educativos para proteger las poblaciones de cóndores en los sitios aquí estudiados, como herramienta para la conservación de esta especie críticamente amenazada en Colombia.

Palabras-clave: Conservación; Especie en Peligro Crítico; Perspectiva de género; Paisaje rural. 


\section{INTRODUCTION}

Avian scavengers have become important elements in the worldview of many different cultures (PALMA, 1982; IBARRA et al., 2012; PFEIFFER et al., 2015). Despite their important cultural role providing environmental "disposal services", some negative perceptions towards these scavenger species still remain as they are considered potential predators of domestic animals, which results in the continued persecution of these species (MARGALIDA et al., 2014; CAILLY-ARNULPHI et al., 2017). While there are reports of predation of domestic animals by European vultures such as the griffon vulture (Gyps fulvus Hablizl, 1783) (MARGALIDA et al., 2014), and by New World vultures such as the black vulture (Coragyps atratus Bechstein, 1783) (LOWNEY, 1999; AVERY and CUMMINGS, 2004), quantitative information on losses of domestic animals due to avian scavenger attacks is lacking, resulting in the widespread perception that vultures are a threat to domestic animals (MARGALIDA et al., 2014). In the case of the largest New World vulture, the California condor (Gymnogyps californianus Shaw, 1797), there are no documented cases of condors taking live prey (SNYDER and SNYDER, 2000). It is important to expand the local understanding of the food ecology of vultures to promote species conservation strategies.

The distribution of the Andean condor (Vultur gryphus Linnaeus, 1758) extends from the Sierra Nevada de Santa Marta in Colombia, southward along the Andean chain from Venezuela to Argentina and Chile (FERGUSON-LEES and CHRISTIE, 2001; LAMBERTUCCI, 2007). In Colombia, its historical distribution included the three Andean mountain ranges, the Serrania del Perijá and the Sierra Nevada de Santa Marta (RODRÍGUEZ et al., 2006). Due to hunting pressure, loss of habitat, decrease of wild prey and carrion poisoning, the Colombian population has decreased and is currently restricted to the northeast and south of the country (NEGRET, 2001; RODRÍGUEZ et al., 2006; RENJIFO et al., 2016). An effort to recover the Andean condor populations in Colombia was developed between 1989 and 2013. Sixty-nine captive-reared condors, originating from United States and Colombian zoos, were released in eight population nuclei within the historical range of the condor (LIEBERMAN et al., 1993; RODRÍGUEZ et al., 2006; RESTREPO-CARDONA et al., 2018). One of the release sites for reintroduction was the protected area Parque Nacional Natural - PNN (National Natural Park) Los Nevados in the Central Andes. The last record for wild condors in this site was 1967 (HERRERA-OSPINA unpublished). From 1997 to 1999, 14 juvenile condors were released in the PNN Los Nevados. It is estimated that the population of $V$. gryphus has approximately 122 individuals of which at least 32 are reintroduced, but there is only reproductive evidence of a pair from the population nuclei of the PNN Los Nevados (ZULUAGA, 2010; ARANGO et al., 2016; RESTREPO-CARDONA et al., 2018). Due to its current low numbers and limited distribution in Colombia, the species is listed as Critically Endangered locally (ARANGO et al., 2016; RENJIFO et al., 2016) and Near Threatened globally (BIRDLIFE INTERNATIONAL, 2019).

The Andean condor has long been considered a key biocultural icon of the South American landscape, recognized for its cultural importance in the regions where it lives (IBARRA et al., 2012). Condors play a key role in the cosmology of different Amerindian peoples and other social groups of the Andes and are included in the national shields of Colombia, Ecuador, Bolivia and Chile (IBARRA et al., 2012). Despite their cultural importance, the negative perceptions of Argentinean rural settlers towards $V$. gryphus, as it relates to the possible predation of domestic animals such as sheep and cattle, can result in persecution of the species (CAILLY-ARNULPHI et al., 2017; MANZANO-GARCÍA et al., 2017). These perceptions, far from being uniform, may vary according to the gender and age of the people (RESTREPO-CARDONA and ENRÍQUEZ, 2014; WHITE et al., 2018).

Traditional knowledge and human perceptions of wildlife can be defined as the knowledge and appreciation of nature transmitted locally through several generations, which ultimately can influence the collective attitude towards native species (COCKER and MIKKOLA, 2000; RESTREPOCARDONA and ENRÍQUEZ, 2014; CAILLY-ARNULPHI et al., 2017). In this regard, initiatives to protect condor populations should take into account the traditional knowledge and perceptions towards the species, thus constituting an important foundation for planning future management and conservation actions.

The purposes of this study are (1) to analyze the range of traditional knowledge about the food types of the Andean condor between adult women and adult men, and between adults and young people, and (2) to describe the perceptions of rural inhabitants towards V. gryphus in the Central Andes of Colombia. 


\section{MATERIAL AND METHODS Study area}

The study was conducted in the rural areas in the buffer zone of the PNN Los Nevados, in the departments of Caldas and Tolima, in an elevational range between 2,210m and 4,081 $\left(04^{\circ} 50^{\prime} 694^{\prime \prime} \mathrm{N}\right.$, $75^{\circ} 15^{\prime} 4.00^{\prime \prime} \mathrm{W}$ ) (Figure 1). In the municipalities of Villamaría and Manizales, department of Caldas, the 15 localities surveyed were: Papayal, La Guayana, El Castillo, Santo Domingo, El Recodo, El Valle, Montenegro, La Telaraña, Playalarga, Potosí, La Esperanza, Los Frailes, Brisas, La Selva, and El Desquite. In the municipalities of Hervéo and Murillo, department of Tolima, the 10 localities surveyed were: Alto de Letras, Santa Inés, El Sifón, Cerro Bravo, La Cabaña, Alfombrales, Sabanalarga, Rosarito, Santa Bárbara, and El Oso. In the buffer zone of the PNN Los Nevados, the highest elevations are classified as páramo, where frailejonales (Espeletia spp.), pajonales (Calamagrostis sp.) and chuscales (Chusquea tessellata) predominate (RANGEL-CH, 2000); while the lower elevation areas are classified as very humid montane forest (HOLDRIDGE, 1967). This lower elevation landscape is a mosaic of riparian, secondary and primary Andean forests, pine forest plantations (Pinus patula), open areas for livestock, agricultural crops and human settlements (pers. obs.).

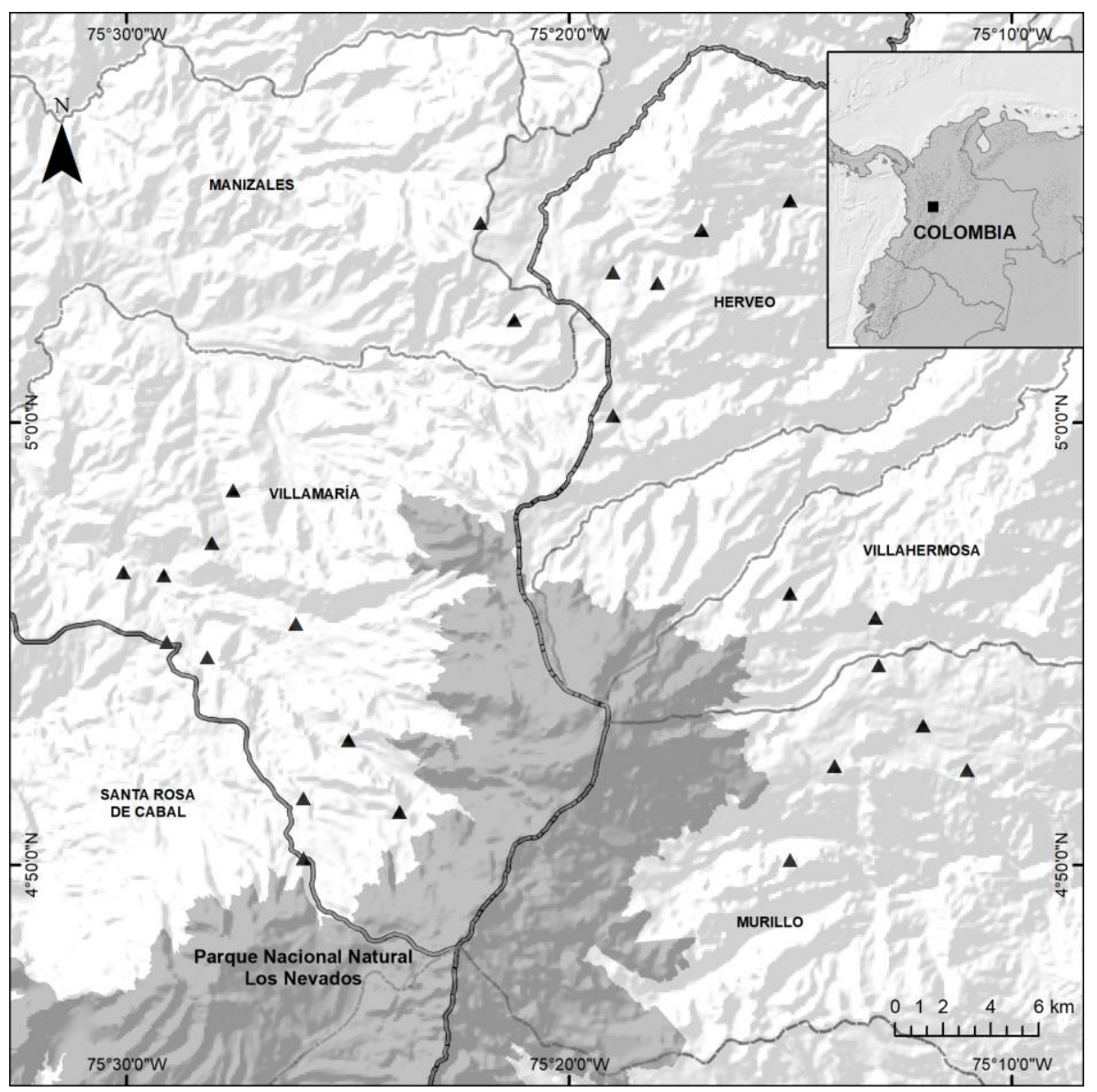

Figure 1. Geographic distribution of the 25 localities surveyed between 2016 and 2017 to document the traditional knowledge and the perceptions towards the Andean condor (Vultur gryphus) in the Central Andes of Colombia. Each triangle represents a locality where inquiries were made of community members.

\section{Field work}

Between 2016 and 2017 we conducted a total of 243 interviews (103 women and 140 men, and 177 adults and 66 young people) of the rural residents living in the buffer zone of the PNN Los Nevados. The goal was to document the traditional knowledge and perceptions of the local population regarding the natural history of $V$. gyphus. The survey consisted of a three part questionnaire. First, we gathered information about the sex, age and educational level of the people surveyed. Then we noted the informant's response to questions about the food types of $V$. gyphus and about people's perceptions towards the species. Finally, we included the following questions: "Have you suffered livestock losses due to attacks of the Andean condor? Would you be willing to support the conservation of the Andean condor? Do you believe the Andean condor has any symbolic value for the region and the country?" 
We visited the homes and schools in each locality, and focal questions were presented orally to women and men over 15 years of age, since at that age it is estimated that the local citizens reach the status of "young adults" in rural Andean communities of Colombia (OSORIO, 2005). Informants were placed into two categories (considered two independent generations); those between the ages of 15 to 26 were considered young adults and those older than 40 were considered to be full adults. The people interviewed were informed of the purpose of the research project and gave their informed consent to participate in the survey, in accordance with the guidelines of the International Society of Ethnobiology. A Chi-square test of independence was applied to all responses to determine the difference in people's knowledge of the types of food of the Andean condor. The information on the perceptions towards $V$. gryphus was analyzed in a descriptive way.

\section{RESULTS}

In the buffer zone of the PNN Los Nevados in Caldas and Tolima, adults mentioned that pastures on farms $(46 \%)$ and rocky escarpments in mountains (43\%) are the sites where condors have been observed most often, followed by crop fields (7\%), forests (2\%) and photos in magazines and books $(2 \%)$. In the case of young people, they mentioned the rocky escarpments in the mountains (32\%) and the pastures on the farms (29\%) as the sites where they have most often observed V. gryphus, but also mentioned television (23\%) and photos in magazines, books, and educational materials (16\%). The majority of the respondents completed only primary education (elementary school; 64.6\%), followed by those who completed secondary education (high school; 25.1\%) and those who confirmed not having received any formal education (8.2\%). A few respondents (2\%) had some or completed higher education (college or university). 92\% of respondents mentioned having livestock on their farm. No adult mentioned having suffered livestock losses due to condor attacks during the time they lived in the area. Only one adult man mentioned that he would not be willing to support the conservation of V. gryphus. Most adults and young people recognize that the species has a symbolic value for the region and the country (96\% and $97 \%$, respectively).

\section{Andean condor diet}

The majority of adults and youths mentioned dead cattle as the main food of the Andean condor, followed by the category "other dead animals", but young people mentioned other prey such as mice, snakes and fish, and other domestic animals such poultry and also seeds (Table 1). Significant differences were found regarding knowledge about the type of food consumed by V. gryphus between adult women and men $\left(X^{2}: 3.83, \mathrm{P}: 0.05\right)$ and also between adults and young people $\left(X^{2}: 4.74, \mathrm{P}: 0.02\right)$.

Table 1. Percentage of respondents $(\mathrm{N}=243)$, by age class and gender, who mentioned the different foods consumed by the Andean condor in the Central Andes of Colombia.

\begin{tabular}{lcccc}
\hline Type of Food & $\begin{array}{c}\text { Adult Men } \\
(\boldsymbol{\%})\end{array}$ & $\begin{array}{c}\text { Adult Women } \\
(\boldsymbol{\%})\end{array}$ & $\begin{array}{c}\text { Young Women } \\
(\boldsymbol{\%})\end{array}$ & $\begin{array}{c}\text { Young Men } \\
(\boldsymbol{\%})\end{array}$ \\
\hline Mice & 0 & 0 & 3 & 6 \\
Snakes & 0 & 0 & 3 & 0 \\
Fish & 0 & 0 & 3 & 0 \\
Seeds & 0 & 0 & 3 & 0 \\
Poultry & 0 & 0 & 0 & 3 \\
Dead cattle & 94 & 69 & 77 & 81 \\
Other dead animals & 6 & 40 & 34 & 35 \\
Not sure & 0 & 1 & 11 & 10 \\
Number of respondents & 109 & 68 & 35 & 31 \\
\hline
\end{tabular}

\section{Perceptions towards the Andean condor}

Perceptions towards the Andean condor varied; most adults considered them harmless, some adults considered them harmful animals or admitted to not knowing how to classify them as either harmful or beneficial. Most of the young people classified the condors as beneficial animals, fewer considered them as harmless and a few were not sure if condors were beneficial or harmful. The smallest percentage of young people considered V. gryphus as a harmful animal (Table 2). 
Table 2. Percentage of respondents $(\mathrm{N}=243)$, by age class and gender, who described their perceptions towards the Andean condor in the Central Andes of Colombia.

\begin{tabular}{lcccc}
\hline Perceptions & $\begin{array}{c}\text { Adult Men } \\
(\boldsymbol{\%})\end{array}$ & $\begin{array}{c}\text { Adult Women } \\
(\boldsymbol{\%})\end{array}$ & $\begin{array}{c}\text { Young Women } \\
(\boldsymbol{\%})\end{array}$ & $\begin{array}{c}\text { Young Men } \\
(\boldsymbol{\%})\end{array}$ \\
\hline Beneficial & 41 & 42 & 51 & 52 \\
Harmful & 6 & 0 & 3 & 0 \\
Not sure & 0 & 3 & 6 & 6 \\
Number of respondents & 109 & 68 & 35 & 31 \\
\hline
\end{tabular}

\section{DISCUSSION}

The majority of adults and youth recounted having seen the Andean condor in the field, but young people also reported being familiar with the species through television, magazines, books, and educational materials. The perceived diet of Andean condors was a category in which the responses differed between adult women and men and between adult and young people. Most adults and young respondents mentioned cattle as the main food of $V$. gryphus, whilst some young people mentioned seeds as a food source for these birds.

The information that exists about the diet of the Andean condor is limited, but historical reports suggest that the condors fed mainly on guanacos (Lama guanicoe Müller, 1776) and lesser rhea (Rhea pennata D'orbigny, 1834) (NOVARO and WALKER, 2005). However, the populations of these prey species were significantly reduced after the European colonization and the introduction of domestic animals such as sheep, goats, cows and horses, which are presently ubiquitous throughout the range of $V$. gryphus (LAMBERTUCCI et al., 2009). This decrease in native vertebrate species populations and the increase in the populations of domestic animals led to a change in the diet of the Andean condor in Argentina, which is currently composed mainly of exotic herbivores such as sheep (Ovis aries Gmellin, 1774), red deer (Cervus elaphus Erxleben, 1777), cattle (Bos taurus LINNAEUS, 1758) and European hare (Lepus europaeus Pallas, 1778) (LAMBERTUCCI et al., 2009; BALLEJO et al., 2017). There is no current information about the diet of the Andean condor for Colombia.

Our results confirm that the perceptions towards the Andean condor were mostly positive (see Table 2). In the communities surveyed in recent years, such as Playalarga, Santa Bárbara, Alfombrales, El Oso and El Sifón, educational campaigns have been developed to encourage positive attitudes towards V. gryphus. These conservation education programs have been part of the reintroduction and monitoring program in the Los Nevados National Natural Park (see CORPOCALDAS, 2010; 2014; 2016; ZULUAGA et al., 2016). In the San Juan Province, Argentina, the perceptions of rural settlers towards V. gryphus were mostly negative and related to the perceived losses of livestock (CAILLYARNULPHI et al., 2017), where, historically and recently, educational programs focused on the conservation of condors have not been developed (CAILLY-ARNULPHI pers. com.). This highlights the importance of educational programs designed to encourage positive attitudes towards $V$. gyphus as a tool for the conservation of the species in Andean rural landscapes.

In our study area, most of the respondents mentioned their willingness to support the conservation of $V$. gryphus. This may be due to the fact that most people now value condors as an iconic symbol for their region and their country. Similarly, in Argentina, although the perceptions towards the Andean condor were mostly negative, a large percentage of the rural population mentioned their willingness to support its conservation and recognized the symbolic value of the species (CAILLYARNULPHI et al., 2017). The Andean condor has generated a special fascination in different indigenous and peasant cultures of the Andes in Colombia. In the Central Andes there are historical records in which the rural population has recognized condors as legitimate protectors of the natural riches of the region and the country (BARRERA, 1977; PALMA, 1982). The species must be promoted, maintained and conserved as a natural and cultural heritage of Colombia, where the rural communities recognize the important ecological and cultural role of this species and its benefits to the ecosystem.

\section{CONCLUSIONS}

Adult men have a better knowledge of the diet of $V$. gryphus compared to adult women. Natural history knowledge is also greater in adults than in young people. The increased familiarity of condor natural history by adult men corresponds to their time spent in the field and their familiarity with the birds of the region. Young people receive information through other elements such as television, magazines and zoos (COCKER and MIKKOLA, 2000; RESTREPO-CARDONA and ENRÍQUEZ, 2014; CAILLY-ARNULPHI et al., 2017). For conservation purposes, it is important to integrate the 
gender perspective into social research initiatives and educational programs to protect the populations of condors in rural regions of the South American Andes.

To quantify the effect that conservation education has imparted on the local communities' perceptions of condors and how it may be of benefit to future Andean condor conservation, it would be valuable to survey a similar human population in an area where condors continue to persist but is lacking any conservation education component. Perceptions as to the value of condors to the local ecology, their value as an iconic regional symbol and their conservation could be compared and measured to establish the impact (positive, negative, neutral) of an imbedded conservation education program. In those areas where condors are being reintroduced as well as where native populations persist, we recommend establishing and maintaining environmental education programs to continue public awareness about condors, with an emphasis on adult women and young people, who may have less knowledge about the ecology of the species. Only by educating the local human populations will the condor be protected and allowed to thrive.

\section{ACKNOWLEDGEMENTS}

This research was made possible by the support of the Parque Jaime Duque. We thank the rural communities in the departments of Caldas and Tolima for their valuable participation in this survey as well as recognizing the participation of Daniela Velazquez, Juan David Salazar and Carlos Valderrama for their assistance in the field. We also thank an anonymous reviewer and Eraldo Medeiros for their comments on the manuscript.

\section{REFERENCES}

ARANGO, S.; ARENAS, D.; ZULUAGA, S.; SÁENZ-JIMÉNEZ, F. Vultur gryphus. In: RENJIFO, L.M.; AMAYA-VILLARREAL, A.M.; BURBANO-GIRÓN, J.; VELÁSQUEZ-TIBATÁ, J. (eds.), Libro rojo de aves de Colombia, ecosistémas abiertos, secos, insulares, acuaticos continentales, marinos, tierras altas del Darien y Sierra Nevada de Santa Martay bosques humedos del centro, norte y oriente del país. Editorial Pontificia Universidad Javeriana e Instituto Alexander von Humboldt, Bogota, Colombia, p. 150-157, 2016.

AVERY, M. L.; CUMMINGS, J. L. Livestock depredations by black vultures and golden eagles. Sheep and Goat Research Journal, v. 19, p. 58-63, 2004.

BALLEJO, F.; LAMBERTUCCI, S. A.; TREJO, A.; DE SANTIS, L. J. M. Trophic niche overlap among scavengers in Patagonia supports the condor-vulture competition hypothesis. Bird Conservation International, v. 28 , p. 390-402, 2017.

BARRERA, R. M. El cóndor andino: el señor de los nevados, mensajero del sol. Corporación Autónoma Regional de Cundinamarca/Fundación. RenaSer, Manizales, Colombia, 1977.

BIRDLIFE INTERNATIONAL. Vultur gryphus. IUCN Red List of Threatened Species. Available at: <http://www.iucnredlist.org>. Accessed on: 7 Feb. 2019.

CAILLY-ARNULPHI, V. B.; LAMBERTUCCI, S. A.; BORGHI, C. E. Education can improve the negative perception of a threatened long-lived scavenging bird, the Andean condor. PLoS ONE, v. 12, e0185278, 2017.

COCKER, M.; MIKKOLA, H. Owls and traditional culture in Africa. Tyto, v. 5, p. 174-186, 2000.

CORPOCALDAS. Monitoreo y talleres de educación ambiental de la población del cóndor andino Vultur gryphus liberada en el Parque Nacional Natural Los Nevados y su zona amortiguadora. Corporación Autónoma Regional de Caldas, Manizales, Colombia, 2010.

CORPOCALDAS. Dinámica poblacional y rango de acción de los cóndores del Parque Nacional Natural Los Nevados. Corporación Autónoma Regional de Caldas, Manizales, Colombia, 2014.

CORPOCALDAS. Monitoreo poblacional a través del seguimiento y censos simultáneos de cóndor andino Vultur gryphus y educación ambiental en torno a la especie en las jurisdicciones de CORPOBOYACÁ y CORPOCALDAS. Corporación Autónoma Regional de Caldas, Manizales, Colombia, 2016.

FERGUSON-LEES, J., CHRISTIE, D. Raptors of the World. Houghton Mifflin Company, Boston, USA, 2001.

HOLDRIDGE, L.R. Life Zone Ecology. Tropical Science Center, San José, Costa Rica, 1967.

IBARRA, J.T.; BARREAU, A.; MASSARDO, F.; ROZZI, R. El Cóndor Andino: una especie biocultural clave del paisaje Sudamericano. Boletín Chileno de Ornitología, v. 18, p. 1-22, 2012.

LAMBERTUCCI, S. A. Biología y Conservación del Cóndor Andino en Argentina. El Hornero, v. 22, p. 149$158,2007$.

LAMBERTUCCI, S. A.; Trejo, A.; DiMartino, S.; Sánchez-Zapata, J. A.; Donázar, J. A.; Hiraldo, F. Spatial and temporal patterns in the diet of the Andean Condor: ecological replacement of native fauna by exotic species. Animal Conservation, v. 12, p. 338-345, 2009.

LIEBERMAN, A.; RODRÍGUEZ, J. V.; PAEZ, J. M.; WILEY, J. The reintroduction of the Andean Condor into Colombia, South America: 1989-1991. Oryx, 27, p. 83-90, 1993. 
LOWNEY, M. S. Damage by Black and Turkey Vutures in Virginia, 1990 - 1996. Wildlife Society Bulletin, v. 27, p. 715-719, 1999.

MANZANO-GARCÍA, J.; JIMÉNEZ-ESCOBAR, N. D.; LOBO, R.; CAILLY-ARNULPHI, V. B. El cóndor andino (Vultur gryphus): ¿predador o carroñero? pluralidad de percepciones entre los saberes locales y el discurso académico en las sierras centrales de Argentina. El Hornero, v. 32, p. 29-37, 2017.

MARGALIDA, A.; CAMPIÓN, D.; DONÁZAR, J. A. Vultures vs livestock: conservation relationships in an emerging conflict between humans and wildlife. Oryx, v. 48, p. 172-176, 2014.

NEGRET, A. J. Aves en Colombia amenazadas de extinción. Serie de Estudios de la Naturaleza. Universidad del Cauca, Popayán, Colombia, 2001.

NOVARO, A. J.; WALKER, R. S. Human-induced changes in the effect of top carnivores on biodiversity in the Patagonian steppe. In: RAY, J.C.; REDFORD, K.H.; STENECK, R.S.; BERGER, J. (eds.), Large carnivores and the conservation of biodiversity. Island Press., Washington, D.C., U.S.A., p. 268-288, 2005.

OSORIO, F. E. Jóvenes rurales y acción colectiva en Colombia. Nómadas, v. 23, p. 122-131, 2005.

PALMA, M. El cóndor: dimensión mítica del ave sagrada. Caja de Crédito Agrario, Industrial y Minero, Bogotá, Colombia, 1982.

PFEIFFER, M. B.; VENTER, J. A.; DOWNS, C. T. Identifying anthropogenic threats to Cape Vultures Gyps coprotheres using community perceptions in communal farmland, Eastern Cape Province, South Africa. Bird Conservation International, v. 25, p. 353-365, 2015.

RANGEL-CH, J. O. La región paramuna y franja aledaña en Colombia. In: RANGEL-CH, J.O. (ed.), Diversidad Biótica III. La región de vida paramuna. Instituto de Ciencias Naturales. Universidad Nacional de Colombia, Bogota, Colombia, 2000.

RENJIFO, L. M.; AMAYA-VILLARREAL, A. M.; BURBANO-GIRÓN, J.; VELÁSQUEZ-TIBATÁ, J. Libro rojo de aves de Colombia. Vol II: Ecosistemas abiertos, secos, insulares, acuáticos continentales, marinos, tierras altas del Darién y Sierra Nevada de Santa Marta y bosques húmedos del centro, norte y oriente del país. Pontificia Universidad Javeriana e Instituto Alexander von Humboldt, Bogotá, Colombia, 2016.

RESTREPO-CARDONA, J. S.; ENRÍQUEZ, P. L. Conocimiento popular sobre los búhos en poblaciones rurales del suroccidente de Manizales, Caldas, Colombia. Etnobiología, v. 12, p. 41-48, 2014.

RESTREPO-CARDONA, J. S.; SÁENZ-JIMÉNEZ, F.; ECHEVERRY-GALVIS, M. A.; BETANCUR, A.; QUINTERO, A. F.; LÓPEZ, P. A. Breeding behavior of a reintroduced pair of Andean Condor in the central Andes of Colombia. Ornitología Neotropical, v. 29, p. 129-133, 2018.

RODRÍGUEZ, C. L.; BARRERA-RODRÍGUEZ, M.; CIRI-LEÓN, F. Programa Nacional para la Conservación del Cóndor Andino en Colombia: Plan de Acción 2006 - 2016. Ministerio de Ambiente, Vivienda y Desarrollo Territorial y CORPOBOYACÁ, Bogotá, Colombia, 2006.

SNYDER, N.; SNYDER, H. The California condor; a saga of natural history and conservation. Academic Press, USA, 2000.

WHITE, J.; KEMMELMEIER, M.; BASSETT, S.; SMITH, J. Human perceptions of an avian predator in an urban ecosystem: close proximity to nests increases fondness among local residents. Urban Ecosystems, v. 21, p. 271-280, 2018.

ZULUAGA, S. Posible evidencia de reproducción de cóndores (Vultur gryphus) reintroducidos en Colombia. Boletín Spizaetus, v. 10, p. 8-11, 2010.

ZUluAGA, S.; OSPINA, O.; CORPOCALDAS. Proyecto de Reintroducción del Cóndor Andino al Parque Nacional Natural Los Nevados: 20 Años. CORPOCALDAS - FUNDACIÓN BIODIVERSA, Manigraf Grupo Editorial, Manizales, Colombia, 2016. 